\title{
Perbandingan Kemampuan Komunikasi Matematika melalui Pembelajaran Quantum dan Pembelajaran Langsung dengan Memperhitungkan Kemampuan Awal Siswa
}

\author{
Misveria Villa Waru \\ STMIK Lamappapoleonro Soppeng \\ e-mail: $\underline{\text { missveriaa@gmail.com }}$
}

\begin{abstract}
ABSTRAK
Jenis penelitian ini adalah eksperimen yang melibatkan dua kelompok yang diberi perlakuan yang berbeda. Penelitian ini bertujuan untuk mengetahui 1) bagaimana tingkat kemampuan komunikasi matematika siswa yang diajar menggunakan pembelajaran quantum, 2) bagaimana kemampuan komunikasi matematika siswa yang diajar menggunakan pembelajaran langsung, 3) Apakah kemampuan komunikasi matematika siswa yang diajar melalui pembelajaran quantum lebih tinggi daripada melalui pembelajaran langsung. Populasi dalam penelitian ini adalah seluruh siswa kelas VII SMPN Watansoppeng semester genap tahun ajaran 2011/2012 yang berstatus SSN yang terdiri dari 8 sekolah dan dipilih 2 sekolah dan setiap sekolah dipilih 1 kelas sebagai sampel penelitian. Teknik pengumpulan data dilakukan dengan menggunakan tes kemampuan komunikasi matematika. Data dianalisis dengan menggunakan teknik analisis statistika deskriptif dan inferensial. Hasil yang diperoleh dari analisis statistika deskriptif adalah: 1) kemampuan komunikasi matematika siswa melalui pembelajaran quantum berada pada kategori baik, 2) kemampuan komunikasi matematika siswa melalui pembelajaran langsung berada dalam kategori sedang. Melallui hasil analisis statistika inferensial diperoleh kemampuan komunikasi matematika melalui pembelajaran quantum lebih tinggi daripada kemampuan komunikasi matematika melalui pembelajaran langsung dengan memperhitungkan kemampuan awal siswa.
\end{abstract}

Kata kunci: Kemampuan Komunikasi Matematika, Pembelajaran Quantum, Pembelajaran Langsung

\begin{abstract}
This research is experiment involving two groups which were given different treatments. These research goals are to know 1) how level of students' mathematical communication ability taught by using Quantum Learning, 2) how level of students' mathematical communication ability taught by using Direct Instruction, 3) whether mathematical communication ability through Quantum Learning is higher than mathematical communication ability through Direct Instruction. Population in this research is all of students grade VII SMPN Watansoppeng even Semester year 2011/2012 whose status is SSN. Consist of 8 schools and chosen 2 schools and the each school chosen 1 class as research sample. Technique of collecting data is using mathematical communication ability test. The data is analyzed by using descriptive statistic and inferential. The result was get from descriptive statistic analyze are: 1) mathematical communication ability through quantum learning having good category, 2) mathematical communication ability through direct instruction having middle category. Result of inferential statistic analyze was get that mathematical communication ability trough quantum learning is higher than mathematical communication ability through direct instruction by considering students' initial ability.
\end{abstract}

Keywords: Mathematical Communication Ability, Quantum Learning, Direct Instruction

\section{PENDAHULUAN}

Berdasarkan pengamatan pada siswa SMP kelas VII, rendahnya kemampuan komunikasi matematika siswa salah satunya terlihat pada pembahasan materi Himpunan dan Garis dan Sudut. Pada materi tersebut, dibutuhkan kemampuan siswa menyajikan masalah dalam bentuk gambar, diagram, tavel ataupun simbol. Setelah itu bagaimana siswa melakukan manipulasi matematika dalam 
menyelesaikan masalah. Dengan kata lain, pada materi tersebut dibutuhkan kemampuan komunikasi matematika siswa yang lebih dibandingkan dengan materi lainnya.

Peningkatan kemampuan komunikasi siswa dapat dilakukan dengan mengadakan perubahan-perubahan dalam pembelajaran. Oleh karena itu guru diharapkan menggunakan model-model pembelajaran yang didalamnya terdapat metode baru yang membiasakan siswa untuk mengkonstruksi sendiri pengetahuannya sehingga siswa mampu mengkomunikasikan ide matematikanya dan dapat menarik kesimpulan dari apa yang mereka peroleh baik dari guru atau teman.

Menurut Kardi dan Nur (2009: 43), pembelajaran langsung menggunakan metode yang dapat berupa ceramah, demonstrasi, pelatihan atau praktik. Pada awal pembelajaran, guru perlu membentuk suatu sikap mental yang positif, atau sikap kesiapan dalam diri siswa. Guru perlu membangkitkan rasa keingintahuan dan minat siswa terhadap pelajaran yang akan mereka peroleh.

Pembelajaran Quantum sendiri merupakan suatu model pembelajaran yang menciptakan suasana pembelajaran yang nyaman dan menyenangkan. Pembelajaran Quantum menggunakan berbagai macam metode ceramah, tanya jawab, diskusi, demonstrasi, kerja kelompok, eksperimen, dan metode pemberian tugas. Teknik-teknik dalam Pembelajaran Quantum ditujukan untuk membantu para siswa menjadi responsive dan bergairah dalam menghadapi tantangan. Aspek-aspek penting dalam program neurolinguistik (NLP), yaitu suatu penelitian tentang bagaimana otak mengatur informasi juga tercakup dalam Pembelajaran Quantum.

Penelitian ini bertujuan untuk mengetahui apakah kemampuan komunikasi siswa yang diajar melalui Pembelajaran Quantum lebih tinggi daripada yang diajar melalui pembelajaran langsung dengan memperhitungkan kemampuan awal siswa.

\section{Kemampuan Komunikasi Matematika}

Komunikasi merupakan bagian yang penting pada pendidikan matematika. Menurut Steinbring (2009: 114), “The mathematical interactions of children during the joint partner work as well as the interaction patterns with which teachers intervene in the children's mathematical communication are being investigated".

Shadiq (2004:20) mengemukakan bahwa kemampuan komunikasi matematika adalah kemampuan seseorang dalam mengkomunikasikan ide-ide dan pikiran matematika. Komunikasi ide-ide, gagasan pada operasi atau pembuktian matematika banyak melibatkan kata-kata, lambang matematika dan bilangan. Muhkal (2009:210), "kemampuan komunikasi matematika adalah kemampuan mengkomunikasikan gagasan dengan bahasa melalui model matematika yang dapat berupa kalimat dan persamaan matematika, diagram, grafik, dan tabel."

Asikin (2002: 492), pengertian kemampuan komunikasi siswa mencakup dua hal yakni menggunakan matematika sebagai alat komunikasi (bahasa matematika) dan kemampuan siswa mengkomunikasikan matematika yang dipelajari sebagai isi pesan yang harus disampaikan.

Herdian (2010) menegaskan bahwa: Kemampuan komunikasi matematika dapat diartikan sebagai suatu kemampuan siswa dalam menyampaikan sesuatu yang diketahuinya melalui peristiwa dialog atau saling berhubungan yang terjadi di lingkungan kelas, dimana terjadi pengalihan pesan. Pesan yang dialihkan berupa konsep, rumus, atau strategi penyelesaian suatu masalah. Cara pengalihan pesannya dapat secara lisan maupun tertulis. 
Tabel 1. Penskoran pada Komunikasi Matematika dalam Pembelajaran Matematika

\begin{tabular}{|c|c|c|c|}
\hline Skor & $\begin{array}{c}\text { Menulis } \\
\text { (written texts) }\end{array}$ & $\begin{array}{l}\text { Menggambar } \\
\text { (Drawing) }\end{array}$ & $\begin{array}{c}\text { Ekspresi Matematika } \\
\text { (Mathematical Expression) }\end{array}$ \\
\hline 0 & \multicolumn{3}{|c|}{$\begin{array}{l}\text { tidak ada jawaban, kalaupun ada hanya memperlihatkan tidak memahami konsep sehingga } \\
\text { informasi yang diberika tidak berarti apa-apa. }\end{array}$} \\
\hline 1 & $\begin{array}{l}\text { Hanya sedikit dari penjelasan } \\
\text { yang benar. }\end{array}$ & $\begin{array}{l}\text { Hanya sedikit dari } \\
\text { gambar, diagram, atau } \\
\text { tabel yang benar. }\end{array}$ & $\begin{array}{l}\text { Hanya sedikit dari model } \\
\text { matematika yang benar. }\end{array}$ \\
\hline 2 & $\begin{array}{l}\text { Penjelasan secara matematis } \\
\text { masuk akal namun hanya } \\
\text { sebagian lengkap dan benar. }\end{array}$ & $\begin{array}{l}\text { Melukiskan diagram, } \\
\text { gambar, atau tabel } \\
\text { namun kurang lengkap } \\
\text { dan benar }\end{array}$ & $\begin{array}{l}\text { Membuat model matematika } \\
\text { dengan benar, namun salah } \\
\text { dalam mendapatkan solusi }\end{array}$ \\
\hline 3 & $\begin{array}{l}\text { Penjelasan secara matematis } \\
\text { masuk akal dan benar, } \\
\text { meskipun tidak tersusun } \\
\text { secara logis atau terdapat } \\
\text { sedikit kesalahan bahasa. }\end{array}$ & $\begin{array}{l}\text { Melukiskan diagram, } \\
\text { gambar atau tabel } \\
\text { secara lengkap dan } \\
\text { benar. }\end{array}$ & $\begin{array}{l}\text { Membuat model matematika } \\
\text { dengan benar, kemudian } \\
\text { melakukan perhitungan atau } \\
\text { mendapatkan solusi secara } \\
\text { benar dan lengkap. }\end{array}$ \\
\hline 4 & $\begin{array}{l}\text { Penjelasan secara matematis } \\
\text { masuk akal dan jelas serta } \\
\text { tersusun secara logis. }\end{array}$ & & \\
\hline & Skor maksimal $=4$ & Skor maksimal $=3$ & Skor maksimal $=3$ \\
\hline
\end{tabular}

Sumber: J.Cai.M.S. Jakabscsin dan S.Lane (Upu, 2003)

\section{Ruang Lingkup Pembelajaran Quantum}

Kata Quantum sendiri berarti interaksi yang mengubah energi menjadi cahaya. Menurut Sudrajat (2008) Pembelajaran Quantum adalah kiat, petunjuk, strategi, dan seluruh proses belajar yang dapat mempertajam pemahaman dan daya ingat, serta membuat belajar sebagai suatu proses yang menyenangkan dan bermanfaat. Selain itu Susilowati (Ediaman, 2010) juga menjelaskan bahwa, Pembelajaran Quantum merupakan

$$
\text { pembelajaran yang }
$$

mengoptimalkan belajar siswa dan motivasi berprestasi siswa.

Lebih lagi, dalam Deporter (2000: 14) mengartikan bahwa, Pembelajaran Quantum sebagai interaksi mengubah energy menjadi pancaran cahaya. Makna lainnya adalah interaksi yang terjadi dalam proses belajar, sehingga mampu mengubah segala potensi yang ada di dalam dirinya menjadi lebih baik dan memperoleh hal-hal yang baru yang dapat ditularkan kepada orang lain.

Tabel 2. Tahap-Tahap Model Pembelajaran Quantum

\begin{tabular}{|c|l|}
\hline Fase & \multicolumn{1}{|c|}{ Aktivitas guru } \\
\hline Tumbuhkan & $\begin{array}{l}\text { Tumbuhkan minat mereka dengan memuaskan "apakah manfaat } \\
\text { bagiku (AMBAK), dan manfaatkan kehidupan pelajar. }\end{array}$ \\
\hline Alami & $\begin{array}{l}\text { Cipatakan atau datangkan pengalaman umum yang dapat dimengerti } \\
\text { semua pelajar. }\end{array}$ \\
\hline Namai & Sediakan kata kunci, konsep, model, rumus \\
\hline Demonstrasikan & $\begin{array}{l}\text { Sediakan kesempatan bagi mereka untuk mengaitkan pengalaman } \\
\text { dengan data yang baru dan tunjukkan bahwa mereka tahu }\end{array}$ \\
\hline Ulangi & $\begin{array}{l}\text { Rekatkan gambaran keseluruhannya. Tunjukkan pelajar cara-cara } \\
\text { mengulang materi }\end{array}$ \\
\hline Rayakan & $\begin{array}{l}\text { Berikan pengakuan untuk penyelesaian, partisipasi, dan pemerolehan } \\
\text { keterampilan dan ilmu pengetahuan. }\end{array}$ \\
\hline
\end{tabular}

Sumber: DePorter dan Hernacki (1999:214) 


\section{Ruang Lingkup Pembelajaran Langsung \\ Model pembelajaran langsung adalah} model pembelajaran yang menekankan pada penguasaan konsep dan/atau perubahan perilaku dengan mengutamakan pendekatan deduktif, dengan ciri-ciri sebagai berikut: 1) transformasi dan keterampilan secara langsung; 2) pembelajaran berorientasi pada tujuan tertentu; 3) materi pembelajaran yang telah terstruktur; 4) lingkungan belajar yang telah terstruktur; dan 5) distruktur oleh guru (Sudrajat: 2008).
Pemikiran mendasar dari model pembelajaran langsung adalah siswa belajar dengan mengamati secara selektif, mengingat dan menirukan tingkah laku guru. Atas dasar pemikiran tersebut, hal penting yang harus diingat dalam penerapan model tersebut adalah menghindari penyampaian yang terlalu kompleks. Guru yang berperan sebagai penyampai informasi seyogyanya menggunakan berbagai media yang sesuai, misalnya tape recorder, gambar, peragaan, dan sebagainya.

Tabel 3. Sintaks Model Pembelajaran Langsung

\begin{tabular}{|l|l|}
\hline \multicolumn{1}{|c|}{ Fase-fase } & \multicolumn{1}{c|}{ Peran Guru } \\
\hline $\begin{array}{l}\text { Fase 1 } \\
\text { memyampaikan tujuan dan }\end{array}$ & $\begin{array}{l}\text { Guru menjelaskan Tujuan pembelajaran, informasi latar } \\
\text { balakang pelajaran, pentingnya pelajaran, } \\
\text { mempersiapkan siswa untuk belajar }\end{array}$ \\
\hline $\begin{array}{l}\text { Fase 2 } \\
\text { Mendemonstrasikan pengetahuan } \\
\text { dan keterampilan }\end{array}$ & $\begin{array}{l}\text { Guru mendemonstrasikan keterampilan dengan benar, } \\
\text { atau menyajikan informasi tahap demi tahap. }\end{array}$ \\
\hline $\begin{array}{l}\text { Fase 3 } \\
\text { Membimbing pelatihan }\end{array}$ & $\begin{array}{l}\text { Guru merencanakan dan memberi bimbingan pelatihan } \\
\text { awal }\end{array}$ \\
\hline $\begin{array}{l}\text { Fase 4 } \\
\text { Mengecek pemahaman dan } \\
\text { memberikan umpan balik. }\end{array}$ & $\begin{array}{l}\text { Mencek apakah siswa telah berhasil melakukan tugas } \\
\text { dengan baik, memberi umpan balik. }\end{array}$ \\
\hline $\begin{array}{l}\text { Fase 5 } \\
\text { Memberikan kesempatan untuk } \\
\text { pelatihan lanjutan dan penerapan }\end{array}$ & $\begin{array}{l}\text { Guru mempersiapkan kesempatan melakukan pelatihan } \\
\text { lanjutan, dengan perhatian khusus pada penerapan kepada } \\
\text { situasi lebih kompleks dan kehidupan sehari-hari }\end{array}$ \\
\hline
\end{tabular}

Sumber: Trianto (2007:3)

\section{Kemampuan Awal}

Tatang (2009) bahwa"Kemampuan awal siswa adalah kemampuan yang telah dimiliki oleh siswa sebelum ia mengikuti pelajaran yang diberikan". Kemampuan awal menggambarkan kesiapan siswa dalam menerima pelajaran yang akan disampaikan. Kemampuan awal penting untuk diketahui guru sebelum memulai pelajaran, karena dengan itu dapat diketahui apakah siswa telah mempunyai pengetahuan awal sebagai prasyarat untuk mengikuti pembelajaran, serta sejauh mana siswa mengetahui materi yang akan disajikan. Dengan kata lain, kemampuan awal siswa merupakan kemampuan yang dimiliki oleh siswa yang membekali siswa dalam proses belajar mengajar selanjutnya.

\section{Hipotesis Penelitian}

Berdasarkan kajian teori, dan kerangka berpikir yang dikemukakan di atas, maka dirumuskan hipotesis sebagai berikut: "Kemampuan komunikasi matematika siswa melalui Pembelajaran Quantum lebih tinggi daripada kemampuan komunikasi matematika siswa melalui pembelajaran langsung dengan memperhitungkan kemampuan awal siswa."

Untuk keperluan pengujian statistic, hipotesis penelitian dirumuskan sebagai berikut:

$$
H_{0}: \mu_{1} \leq \mu_{2} \text { Lawan } H_{1}: \mu_{1}>\mu_{2} \text { (1) }
$$


dengan $\mu_{1}=$ Rata-rata kemampuan komunikasi matematika siswa yang diajar melalui pembelajaran Quantum dan $\mu_{2}=$ Rata-rata kemampuan komunikasi matematika siswa yang diajar melalui pembelajaran langsung.

\section{METODE}

Penelitian ini merupakan jenis penelitian eksperimen, yaitu metode penelitian yang digunakan untuk mencari pengaruh tertentu terhadap yang lain dalam kondisi yang terkendalikan. Untuk kelompok eksperimen diajar dengan menggunakan pembelajaran quantum sedangkan pada kelompok pembanding diajar dengan menggunakan pembelajaran langsung.

Variabel bebas pada penelitian ini adalah pembelajaran quantum dan pembelajaran langsung. Variabel terikat pada penelitian ini adalah kemampuan komunikasi matematika siswa. Variabel kontrol pada penelitian ini kemampuan awal siswa yang merupakan skor kemampuan komunikasi matematika siswa dalam bentuk pretest.

Sampel dalam penelitian ini diambil dengan menggunakan Random Sampling. Teknik ini digunakan karena memperhatikan sekolah yang memiliki akreditasi yang sama dan berstandar SSN. Sekolah yang dijadikan sampel adalah SMPN 3 Watansoppeng dimana kelas VII.khusus sebagai kelompok eksperimen dan SMPN 1 Donri-donri dimana kelas VII.1 sebagai kelompok pembanding.

Desain penelitian yang digunakan adalah desain "Pretest - Posttest Control Design". Dalam desain ini terdapat dua kelompok yaitu kelompok I disebut kelompok eksperimen yang diberikan pretest berupa tes kemampuan komunikasi matematika siswa sebelum diajar dengan model Pembelajaran Quantum dan diberikan Posttest setelah siswa diajar dengan ${ }_{3}^{3}$ model Pembelajaran Quantum. Serta kelompok II disebut kelompok pembanding (kontrol) yang diberikan pretest berupa tes kemampuan komunikasi matematika siswa sebelum diajar dengan pembelajaran langsung dan diberikan posttest setelah siswa diajar dengan pembelajaran langsung.

Pengumpulan data dalam penelitian ini dilakukan dengan melakukan tes awal (pretest) yang berupa tes kemampuan komunikasi matematika serta tes akhir (posttest) pada kelas eksperimen dan kelas kontrol. Jenis data berupa hasil kemampuan komunikasi matematika.Tes kemampuan komunikasi matematika yang digunakan adalah berbentuk essay. Sebelum tes itu digunakan terlebih dahulu diuji cobakan untuk menguji validitas dan reliabilitas instrumen.

Analisis statistika inferensial digunakan untuk menguji hipotesis penelitian dengan menggunakan Analisis Kovarian (ANAKOVA). Namun sebelum dilakukan pengujian hipotesis, terlebih dahulu dilakukan homogenitas

\section{Model Matematis Anakova}

$$
y=\beta o+\beta_{1} I+\beta_{2} X+\varepsilon
$$

Dimana:

$y$ : Nilai kemampuan komunikasi matematika

$\beta_{0}$ : Intersep garis regresi

$\beta_{1}$ dan $\beta_{2}$ : Koefisien Regresi

I: Nilai kemampuan awal siswa (kovariat)

$$
X\left\{\begin{array}{l}
1, \text { jika pembelajaran quantum } \\
0, \text { jika pembelajaran langsung }
\end{array}\right.
$$

\section{HASIL DAN PEMBAHASAN}

Setelah memperhatikan karakteristik variabel yang telah diteliti dan prasyarat analisis, selanjutnya dilakukan pengujian terhadap hipotesis. Untuk keperluan tentang pengujian hipotesis digunakan statistika inferensial dengan bantuan program SPSS yaitu ANAKOVA. Kriteria pengujiannya adalah jika nilai probability lebih besar dari $\alpha=0.05$, maka $\mathrm{H}_{0}$ diterima atau $\mathrm{H}_{1}$ ditolak artinya tidak ada perbedaan antara dua perlakuan yang diberikan dengan memperhitungkan kemampuan awal siswa. Sebaliknya, jika nilai probability lebih kecil 
dari $\alpha=0.05$, maka $\mathrm{H}_{0}$ ditolak atau $\mathrm{H}_{1}$ diterima, artinya ada perbedaan antara dua

Tabel 4. Hasil Uji ANAKOVA

Test of Between-Subjects Effects

Dependent Variable: $\mathrm{Y}$

\begin{tabular}{|l|r|r|r|r|r|}
\hline Source & $\begin{array}{c}\text { Type III } \\
\text { Sum of } \\
\text { Squares }\end{array}$ & $\begin{array}{c}\text { d } \\
\mathrm{f}\end{array}$ & $\begin{array}{c}\text { Mean } \\
\text { Square }\end{array}$ & F & Sig \\
\hline Correct & 8471.327 & 2 & 4235.6 & 49.44 & .00 \\
ed & a & 1 & 63 & 2 & 0 \\
Model & 4430.212 & 1 & 4430.2 & 51.71 & .00 \\
Interce & 5603.455 & 1 & 12 & 2 & 0 \\
pt & 2864.551 & 4 & 5603.4 & 65.40 & .00 \\
I & 3855.152 & 5 & 55 & 7 & 0 \\
X & 261879.0 & 4 & 2864.5 & 33.43 & .00 \\
Error & 00 & 8 & 11 & 7 & 0 \\
Total & 12326.47 & 4 & 85.670 & & \\
Correct & 9 & 7 & & & \\
ed & & & & & \\
Total & & & & & \\
\hline
\end{tabular}

Hasil analisis menunjukkan bahwa $F_{\text {hitung }}$ $=33.437$ dengan nilai $p=0.0001$, karena nilai $p<\alpha=0.05$ maka $\mathrm{H}_{0}$ ditolak atau $\mathrm{H}_{1}$ diterima. Ini berarti bahwa setelah memperhitungkan/mengontrol kemampuan awal siswa, terdapat perbedaan antara kemampuan komunikasi matematika yang diajar melalui model pembelajaran quantum dengan kemampuan komunikasi matematika yang diajar melalui model pembelajaran langsung.

Selanjutnya perbedaan rata-rata pada kedua kelompok yang homogen yaitu pada kelompok kontrol dan kelompok eksperimen melalui uji contrast menunjukkan bahwa nilai $t_{\text {hitung }}=3,74>t_{\text {table }}=1,68$ dengan $p$-value $=$ $\frac{0,001}{2}=0,0005 \quad<\alpha=0,05$. Dengan demikian $\mathrm{H}_{\mathrm{o}}$ ditolak atau $\mathrm{H}_{1}$ diterima. Ini berarti bahwa kemampuan komunikasi matematika siswa melalui pembelajaran quantum lebih tinggi daripada kemampuan komunikasi matematika siswa melalui pembelajaran langsung dengan memperhitungkan kemampuan awal siswa.

Hasil analisis inferensial menunjukkan bahwa secara signifikan terdapat perbedaan perlakuan yang diberikan dengan memperhitungkan kemampuan awal siswa.

kemampuan komunikasi matematika siswa yang diajar dengan menggunakan model pembelajaran quantum dengan siswa yang diajar menggunakan model pembelajaran langsung dimana kemampuan awal siswa sebagai kovariat. Hal ini ditunjukkan oleh nilai $p=0,001<\alpha=0.05$. Serta hasil dari uji Contrast menunjukkan bahwa kemampuan komunikasi matematika melalui pembelajaran quantum lebih tinggi daripada kemampuan komunikasi matematika melalui pembelajaran langsung dengan memperhatikan kemampuan awal siswa. Hal ini ditunjukkan oleh $p$-value $=0,005$ lebih kecil dari $\alpha=0.05$.

Perbedaan ini juga dapat dilihat dari ratarata kemampuan komunikasi matematika yang diperoleh oleh kedua kelompok. Sehingga dapat disimpulkan bahwa kemampuan komunikasi matematika melalui pembelajaran quantum untuk siswa kelas VII.Khusus SMPN 3 Watansoppeng lebih tinggi daripada kemampuan komunikasi matematika melaui pembelajaran langsung untuk siswa kelas VII.1 SMPN 1 Donri-donri dengan memperhitungkan kemampuan awal siswa.

\section{PENUTUP \\ Kesimpulan}

Setelah dilakukan uji ANAKOVA diperoleh hasil yaitu setelah dikendalilkan oleh kovariat kemampuan awal siswa secara signifikan terdapat perbedaan kemampuan komunikasi matematika antara kelas yang diajar menggunakan model pembelajaran quantum dengan kelas yang diajar menggunakan pembelajaran langsung.

Berdasarkan skor rata-rata antara kelas kontrol dan kelas eksperimen serta hasil dari uji contrast dapat disimpulkan bahwa kemampuan komunikasi 
matematika melalui pembelajaran quantum lebih tinggi daripada kemampuan komunikasi matematika melalui pembelajaran langsung dengan memperhitungkan kemampuan awal siswa.

\section{Saran}

Setelah melihat hasil penelitian yang telah dilakukan, adapun saran yang diajukan penulis adalah:

1. Guru bidang studi matematika di SMP sekiranya dapat menerapkan model pembelajaran Quantum untuk meningkatkan kemampuan komunikasi matematika siswa agar dapat diperhitungkan sebagai salah satu alternatif dalam proses belajar mengajar.

2. Guru-guru di sekolah khususnya guru matematika sebaiknya lebih memperkenalkan musik-musik klasik kepada siswa dalam pembelajarannya, hal ini untuk menunjang kemampuan siswa dalam hal cara berpikir otak mereka.

\section{DAFTAR PUSTAKA}

Asikin, Mohammad. 2002. Menumbuhkan Kemampuan Komunikasi Matematika melalui Pembelajaran Matematika Realistik. Matematika edisi khusus. Hlm 492-496.

DePorter, B \&Hernacki, Mike. 1999 Quantum Learning Membiasakan Belajar Nyaman Dan Menyenangkan. Bandung: Kaifa.

Deporter, B. 2000. Quantum Teaching Mempraktikkan Quantum Learning di Ruang-ruang Kelas. Bandung: Kaifa

Herdian. 2010. Kemampuan Komunikasi Matematika. Jakarta: Wordpress.

Kardi, S dan Nur. 2000. Pengajaran Langsung. Surabaya: University Press.
Muhkal, Mappaita. 2009. Hakikat Matematika dan Hakikat Pendidikan Matematika. Makassar: FMIPA UNM.

National Council of Teacher of Mathematics (NCTM). 1989. Principles and Standards for School Mathematics. Reston: VA: NCTM.

Nurkancana, Wayan. 1986. Evaluasi Pendidikan. Surabaya: Usaha Nasional

Nurudin. 2008. Sistem Komunikasi Indonesia. Jakarta: Rajagrafindo Persada.

Paxman, Christina G. 2011. Map Your Way to Speech Success. Journal of Education for Teaching, 25, p. 7-11.

Sanjaya, Ade. 2011. Karakteristik Quantum Learning. Jakarta: Wordpress.

Santrock, John W. 2008. Psikologi Pendidikan. Jakarta: Kencana.

Shadiq, Fajar. 2004. Pemecahan Masalah, Penalaran dan Komunikasi. Diklat Instruktur/Pengembangan

Matematika SMU. Yogyakarta: Widyaswara PPG Matematika.

Shannon, C.E. 1984. A Mathematical Theory of Communication. The Bell System Tehnical Journal. 27, p. 623656.

Slameto. 2003. Belajar dan Faktor-faktor yang Mempengaruhinya. Jakarta: Rineka Cipta.

Steinbring, Heinz. 2009. Forms of Mathematical Interaction in different social Settings: Examples from Students, Teacher, and Teacher-Students Communication About Mathematics. Journal mathematics Teacher Education, 12, p. 111-132.

Sudrajat, A. 2008. Quantum Learning, Cara Baru Mengubah Kecerdasan. Jakarta: Wordpress. 
Tatang, Ade M. 2009. Pengelolaan Kelas. Garut: Atom Press.

Thomas, Holly K. 2011. Student Responses to Contemplative Practice in a Communication Course. Journal of Education for Teaching, 25, p. 115-126.

Tiro, M. A, 1999. Dasar-Dasar Statistika, State Makassar: University of Makassar Press.

Tiro, M, A. 2010. Cara Efektif Belajar Matematika. Makassar: Andira Publisher

Trianto. 2007. Model-Model Pembelajaran Inovatif Berorientasi Konstruktivistik. Jakarta: Prestasi pustaka.

Upu, Hamzah. 2003. Problem Posing dan Problem Solving. Bandung: Pustaka Ramadhan.

Widjaja, A.W. 1993. Komunikasi dan Hubungan Masyarakat. Jakarta: Bumi Aksara.

\section{RIWAYAT HIDUP PENULIS}

Misveria Villa Waru, S.Pd. M.Pd. Lahir

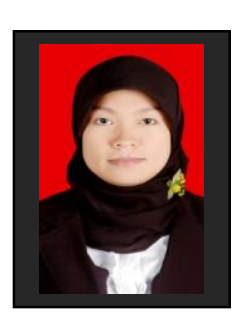
di Soppeng, 25 Juli 1990. Dosen di STMIK Lamappapoleonro Soppeng pada Program Studi Teknik Informatika. Studi S1 Pendidikan Matematika Bilingual Universitas Negeri Makassar, lulus tahun 2012; dan S2 Pendidikan Matematika Universitas Negeri Makassar, lulus tahun 2015. 